\title{
CS-36 - Implementación Zona de Desarrollo Próximo para favorecer la práctica de investigación-educativa
}

\author{
Implementation of the Next Development Zone to promote \\ research-educational practice \\ Luis Carlos Cuahonte Badillo*, Gladys Hernández Romero, Blanca Lilia Ramos González, Jacinta \\ Hernández Pérez, Maritza Concepción Baños Everardo
}

Universidad Juárez Autónoma de Tabasco, México

*Autor a quien se dirige la correspondencia: cuahontebadillo@gmail.com

\section{Resumen}

Con datos que aporta el Primer Informe de Actividades del Rector de la Universidad Juárez Autónoma de Tabasco (2016), se destaca que la licenciatura en Ciencias de la Educación (LCE), institucionalmente participa con el 13\% (60) del total de las titulaciones bajo la modalidad de tesis, que ascendió, en ese año a 468. Este indicador nos muestra que la práctica de la investigación en la LCE es baja. El propósito de la línea curricular de investigación educativa de la LCE establece que se... "proporcionaran los elementos teóricos metodológicos que contribuyan a la conformación progresiva de un perfil de investigador socio-educativo, con la intencionalidad de contribuir al desarrollo de visiones más integrales para acceder al estudio de fenómenos educativos". Para tal efecto se utilizó una metodología mixta, el tipo de investigación exploratorio-descriptivo, la población a la que se aplicó el instrumento de investigación constó de 27 estudiantes inscritos en los grupos de $7^{\circ}: 8^{\circ}$ : y $9^{\circ}$ ciclo escolar agosto 2016-enero 2017. Por tal motivo en este trabajo se describirán las experiencias surgidas de la aplicación de los postulados de la Zona de Desarrollo Próximo (ZDP) cuyo autor es Lev Semiónovich Vygotsky, para brindarle asesorías personalizadas a los estudiantes de la LCE y proporcionarles un acompañamiento en el desarrollo de sus investigaciones y que al concluirlas, alentarlos a que se titulen bajo la modalidad de tesis.

Palabras claves: Investigación, Zona de Desarrollo Próximo, personalización, estudiante

\section{Abstract}

$\mathrm{W}$ ith data provided by the First Activity Report of the Rector of the Autonomous University of Juárez of Tabasco (2016), it is highlighted that the degree in Education Sciences (LCE), institutionally participates with 13\% (60) of the total degrees Under the modality of thesis, which rose to 468 in that year. This indicator shows that the practice of research in the LCE is low. The purpose of the curricular line of Educational Research of the LCE establishes that ... "will provide the theoretical methodological elements that contribute to the progressive formation of a profile of socio-educational researcher, with the intention of contributing to the development of more comprehensive visions to access To the study of educational phenomena ". For this purpose a mixed methodology was used, the type of exploratory-descriptive research, the population to which the research instrument was applied consisted of 27 students enrolled in the 7th: 8th and 9th school years August 2016- January 2017 In this paper we will describe the experiences arising from the application of the postulates of the Zone of Next Development (ZPD) authored by Lev Semyonovich Vygotsky, to provide personalized advice to the LCE students and provide them with an accompaniment in the Development of their research and, upon conclusion, encourage them to be titled under the thesis modality. 